\title{
Hypercoagulability and thrombosis
}

\section{Maria Domenica Cappellini, Erika Poggiali}

University of Milan and Policlinico Foundation IRCCS, Milan, Italy

\section{Oral presentation}

Oral presentation is available online

Correspondence: Erika Poggiali

Acknowledgements: i would like to thank you for the attention, and all the Congenital Anemia Center Staff for their support Prof. M.D. Cappellini, Giovanna Graziadei, Irene Motta, Alessia Marcon, Ilaria Gandolfi, Laura Zanaboni, Marianna Giuditta, Elena Cassinerio, Marta Mazzoleni, Claudia Cesaretti, Silvio De Fazio, all the nursing staff.

(C) Copyright M.D. Cappellini and E. Poggiali., 2013

Licensee PAGEPress, Italy

Thalassemia Reports 2013; 3(s1):e10

doi:10.4081/thal.2013.s1.e10

This article is distributed under the terms of the Creative Commons Attribution Noncommercial License (by-nc 3.0) which permits any noncommercial use, distribution, and reproduction in any medium, provided the original author(s) and source are credited.

Parts of this work were presented at the

"3rd Pan-European Conference on Haemoglobinopathies and Rare Anaemias", Limassol (Cyprus), 24-26 October 2012. 